\title{
EFFECT OF IRRIGATION SCHEDULING ON YIELD, QUALITY AND FUNCTIONAL PROPERTIES OF POTATO TUBERS
}

\author{
Amer, K. H.; ${ }^{1}$ Aboamera, M. A. ${ }^{1}$ and Sallam, M. E. ${ }^{2}$
}

\begin{abstract}
Potato growth, yield, and quality are important parameters under scheduling of surface irrigation using gated pipes to evaluate water management in Nile valley soils. A field experiment was conducted during 18 Jun.-20 May 2015 spring growing season using potato (Solanum tuberosum) grown in northern Egypt at Qusina, Minoufia, Egypt to study potato response, quality and functional properties to different irrigation scheduling levels. A Randomized Split-Plot Design with irrigation scheduling treatments as irrigation levels 75, 60 and $45 \%$ from available water and water cutoff times when water flow was reached the field end (after $5 \mathrm{~min}$, exactly reached and before $5 \mathrm{~m}$ ) were randomly distributed. Non-uniformity of irrigation applications were evaluated along irrigation furrow as dependent variables measured at the (0-20), (20-40) and (40-60) $\mathrm{m}$ along $60 \mathrm{~m}$ irrigation line. Potato tuber yield and quality were significantly affected by irrigation levels (IL), water cutoff time (WCT) and distance from upstream end (D). Tuber yield, water use efficiency, dry matter percentage, percentage of tuber size grade and yield of chips were significantly affected by IL, WCT and $D$, and their interaction $I L * W C T ; W C T * D ; I L * D$ and $I L * W C T^{*} D$ except percentage of tuber size which was non-significantly affected at medium size by (WCT) and large size by interaction $I L^{*} W C T^{*} D$. The highest tuber yield was under treatment irrigation level of $75 \%$ from $A W$ and when water flow was exactly reached the field end. Improving quality and saving water were under both irrigation level of $45 \% A W$ and water cutoff before reaching $5 \mathrm{~m}$ from downstream end.
\end{abstract}

Keyword: surface irrigation; gated pipes; quality and functional properties; tuber yield, water use efficiency, dry matter percentage, percentage of tuber size grade and yield of chips.

\footnotetext{
${ }^{1}$ Professor of irrigation and ${ }^{2}$ Graduate student, Agr. Eng. Dept., Faculty of Agriculture, Menoufia University, Egypt
} 


\section{INTRODUCTION}

The cultivated area of old land is about 2.7 million hectares irrigated by surface irrigation from total cultivated area of 3.9 million hectares according to data issued by Ministry of Agriculture, Egypt in 2013. Despite this progressive water shortage farmers continue to use surface irrigation. Poor management, uniformity and distribution of water have been cited as the most frequent problems of surface irrigation, resulting in waterlogging, salinization and less water use efficiency AbouKheira (2009). Potato is considered one of the main important vegetable ranks as manufacture and export crop among the different vegetable crops in Egypt. About 178 thousand hectares are only cultivated in spring, fall and winter seasons. Total production of potato in Egypt is about four million tons per year.

Bosnjak and Pejic (1997) working on Potato which were given irrigation to $75-80$ or $60-65 \%$ field water capacity (FWC) or without irrigation (control). They found that the yields were highest in the 75-80\% FWC treatment compared to control treatment. Podstawka and Malicki (1997) recorded that average tubers yield was $40.1 \mathrm{t} / \mathrm{ha}$ without irrigation and $47.4 \mathrm{t} / \mathrm{ha}$ with irrigation. Aksic et al. (2012) grew potato plants under different irrigation rates, i.e., irrigated by three treatments with irrigation (soil matrix potential of 20,30 and $40 \mathrm{kPa}$ ) as well as control. Irrigation schedule was determined by tensiometers. They found that total yield increased with increasing irrigation rate.

El-Banna et al (2001) revealed that, specific gravity and percentage of tuber dry matter were significantly increased with decreasing irrigation water rates. On the contrary, Samey (2006) indicated that, specific gravity and percentage of tuber dry matter in two season were significantly increased with decreasing irrigation rates, i.e., irrigation by $50 \%$ of the evapotranspiration, compared with irrigation by 75,100 and $125 \%$ of the evapotranspiration, while, the lowest value of water supply, i.e., irrigation by $125 \%$ of the evapotranspiration also, it ranged from $21.0 \%$ to $23.5 \%$.

Karafyllidis et al (1996) found that, high soil moisture availability levels tended to give higher proportions of large tubers (> $60 \mathrm{~mm}$ ), whereas, small tubers $(<35 \mathrm{~mm})$ were more frequent in the water deficit 
treatments. The percentage of tubers $45-60 \mathrm{~mm}$ was inconsistent, but all treatments had similar proportions of tubers, but all treatments had similar proportions of tubers $35-45 \mathrm{~mm}$.

Samey (2006) showed that the high level of water regimes (irrigation by $125 \%$ of evapotranspiration) led to an insignificant reduction weight after frying. Meanwhile, irrigation by 50\% of evapotranspiration gave the highest value of weight after frying may be due to increasing dry matter content of potato tubers under this condition.

The purpose of the work is to find out the best management of the irrigation scheduling for surface irrigation with gated pipes to give the highest productivity, the best quality and functional properties of potato tubers.

\section{MATERIAL AND METHODS}

Field experiment was conducted in 2015 spring growing season using potato (Solanum tuberosum) grown in northern Egypt at Qusina area, $17.9 \mathrm{~m}$ above sea level, $30^{\circ} 56^{\prime} \mathrm{N}, 31^{\circ} 15^{\prime} \mathrm{E}$, Minoufia, Egypt to study potato response, quality and functional properties to different irrigation scheduling levels. All treatments were irrigated each growing season with the same sufficient water amount using surface irrigation to ensure uniform soil moisture prior to planting. The crop was seeded when soil moisture content was almost $0.39 \mathrm{~m}^{3} \mathrm{~m}^{-3}$ using potato planter on 18 January and terminated on 20 May in the 2015 spring season. A Randomized Split-Plot Design with irrigation scheduling treatments as irrigation levels (75, 60 and 45\% from available water) and water cutoff times when water flow was reached the field end as (after 5 min, exactly reached and before $5 \mathrm{~m}$ ) were randomly distributed. Non-uniformity of irrigation applications were evaluated along irrigation furrow as dependent variables measured at the (0-20), (20-40) and (40-60) $\mathrm{m}$ along $60 \mathrm{~m}$ irrigation line. The outside diameter of pipe is $6 "$ and $6 \mathrm{~m}$ length as shown in Fig. 1. Pipe is made of UPVC with gates spacing 0.75 $\mathrm{m}$. The flow rate out of each gate system is controlled by head inside the pipe to be $11.4 \mathrm{~m}^{3} / \mathrm{h}$ with $22.86 \mathrm{~cm}$ head. Surface irrigation system using gated pipes was divided into three sectors to evaluate the best parameters. Sub-plot area was $60 \mathrm{~m}$ length $\times 2.25 \mathrm{~m}$ width. Each plot was included three furrows with $0.75 \mathrm{~m}$ furrow width. A distance of $1.5 \mathrm{~m}$ was 
between each irrigation treatments. In the gated pipes technique, the pipes were located at the head of the irrigated field across the furrows. Three irrigation levels 75, 60 and 45\% from available water were used with three different water cutoff times in which water flow reached downstream end as $5 \mathrm{~min}$ after, exactly reached and before $5 \mathrm{~m}$.

The soil was clay in texture. The properties of the soil were shown in Table 1 .

The seed tubers of coefficient of variation, Herms were imported from abroad (Scotland UK) was showed at Table 2.

Table 1.The physical properties of the experimental soil.

\begin{tabular}{|l|l|l|l|l|l|l|l|l|}
\hline $\begin{array}{l}\text { Soil } \\
\text { depth }\end{array}$ & Sand & Silt & Clay & $\begin{array}{l}\text { Texture } \\
\text { class }\end{array}$ & $\begin{array}{l}\text { Bulk } \\
\text { density } \\
\mathrm{g} \cdot \mathrm{cm}^{-3}\end{array}$ & $\begin{array}{l}\text { Field } \\
\text { capacity } \\
\%\end{array}$ & $\begin{array}{l}\text { Permanent } \\
\text { wilting } \\
\text { point } \%\end{array}$ & $\begin{array}{l}\text { Available } \\
\text { soil water } \\
\%\end{array}$ \\
\hline $0-20$ & 20.27 & 41.17 & 38.56 & Clay loam & 1.29 & 42.45 & 21.90 & 20.55 \\
\hline $20-40$ & 20.80 & 40.51 & 38.69 & Clay loam & 1.31 & 40.95 & 20.45 & 20.50 \\
\hline $40-60$ & 17.32 & 36.75 & 45.93 & Clay & 1.33 & 38.89 & 19.14 & 19.75 \\
\hline
\end{tabular}

Table 2. Label of using potatoes

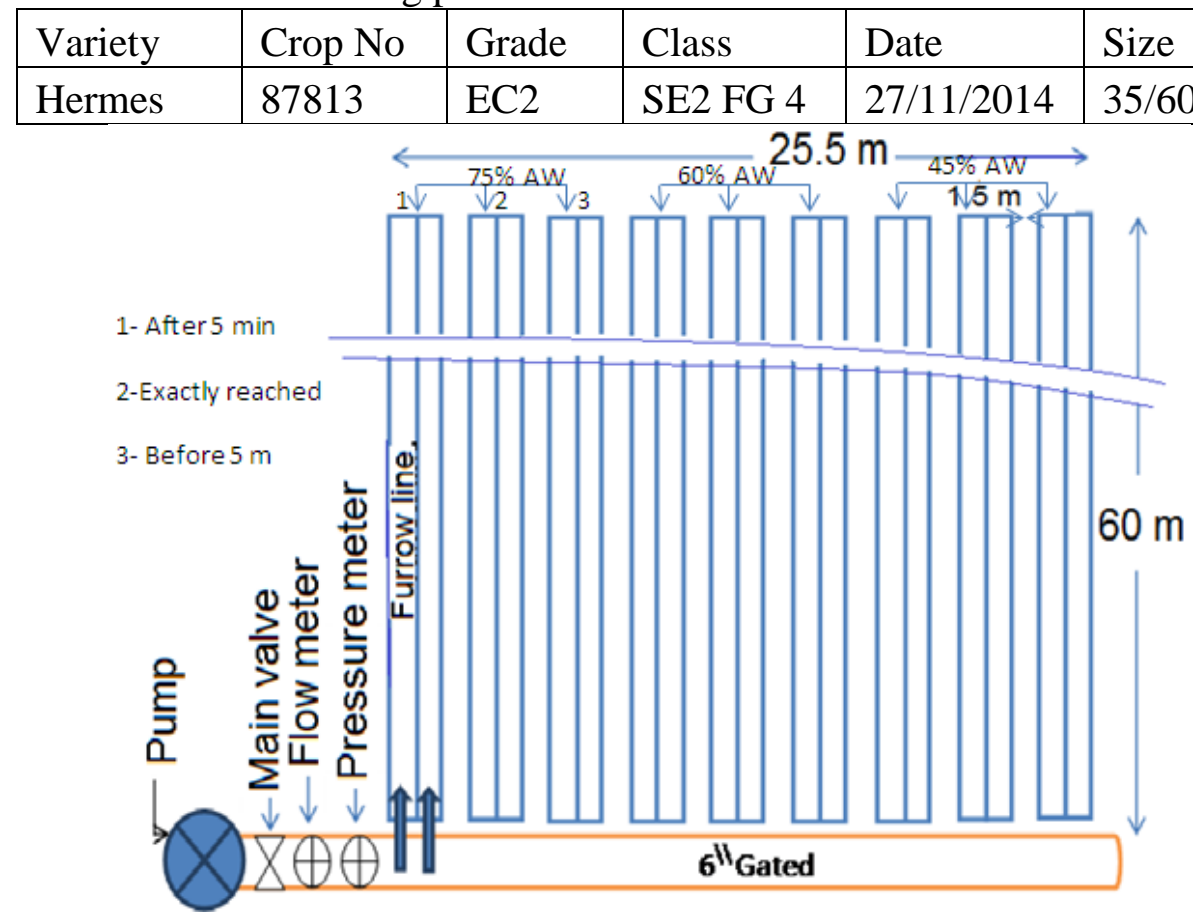

Fig.1. Layout of experimental replicate 
The average weight of the tubers ranged from 40-50 g/tuber. The potato tuber seeds were cured and planted $0.25 \mathrm{~m}$ apart in furrow $60 \mathrm{~m}$ in long and $0.75 \mathrm{~m}$ in width. All cultural practices as well as diseases and pests control applied as recommended by the Egyptian Ministry of Agriculture. All experimental units received identical amounts of composted animal manure $\left(75 \mathrm{~m}^{3} / \mathrm{ha}\right)$ and phosphorus $(200 \mathrm{~kg} / \mathrm{ha})$ using single a calcium super phosphate $\left(15.5 \% \mathrm{P}_{2} \mathrm{O}_{5}\right)$ banded on furrow before planting with agricultural sulfur $\left(300 \mathrm{~kg} / \mathrm{ha} \mathrm{SO}_{4}\right)$. Nitrogen fertilizer was added at the rate of $400 \mathrm{~kg} \mathrm{~N} / \mathrm{ha}$ at four times, planting, first irrigation, and 45 and 60 days from planting, respectively.

Water advance and recession times were functioned of their length at the second irrigation for the mentioned treatments by using field marks and surveying tape, the furrows were divided into number of six stations having equal distances between them $(10 \mathrm{~m})$. Irrigation water advance times into the furrow were recorded at the end of each station. At the upstream end when water started to disappear, recession times were observed and recorded at each station. This mark is the initiation of the water drying or recession front.

The water infiltration opportunity time along furrow length is the difference between the last time when water disappeared and the first time when water started to advance at the same point along furrow. It can be determined according to Amer (2009) as formulated in equation.

$$
\mathrm{t}_{\mathrm{o}}=\mathrm{T}+\mathrm{t}_{\mathrm{r}}-\mathrm{t}_{\ell}
$$

where $t_{o}$ is opportunity infiltrated time into the root zone in minute, $T$ is total time of advance, storage, and depletion phases that started from water turn on and ended when the water at the upstream end disappeared in minutes, $t_{t}$ is advance time in min and $t_{r}$ is recession time in min.

The rate of infiltration was considered as a time dependent process and represented by Kostiakov's equation. Field infiltration rate in soil (I) that was measured in the upper $30 \mathrm{~cm}$ of soil surface using double ring infiltrometer in the beginning of the experiment. Water infiltration rate was determined according to Kostiakov equations ( 2 and 3) were found in the experimental field. It was functioned to opportunity time to in minute for the clay soil as:

$$
\mathrm{I}=5.75 \mathrm{t}_{\mathrm{o}}^{-0.401}
$$


Cumulative infiltrated depth $\mathrm{Z}$ in $\mathrm{mm}$ was integrated from infiltration rate function and reported as

$$
\mathrm{Z}=9.599 \mathrm{t}_{\mathrm{o}}^{0.599}
$$

where $\mathrm{Z}$ in $\mathrm{mm}$ and $\mathrm{t}_{\mathrm{o}}$ in $\min$.

To evaluate the furrow irrigation treatments, the distribution uniformity was taken as a function of coefficient of variation (CV) can be determined according to Amer (2010) as follows:

$$
\mathrm{DU}=1-1.27 \mathrm{CV}
$$

Application efficiency $\left(E_{a}\right)$ was determined as the ratio of water stored in the rootzone to the total water applied when no runoff occurred in blocked furrow. In non uniformity condition, $\mathrm{E}_{\mathrm{a}}$ can be determined according to Amer (2010) as follows:

$$
\mathrm{E}_{\mathrm{a}}=1-\frac{(1.725-\alpha)^{2}}{6.9} C V
$$

In complete surplus irrigation, $\mathrm{E}_{\mathrm{a}}$ can be determined be as follows:

$$
\mathrm{E}_{\mathrm{a}}=1+\alpha C V
$$

The schedule parameter was $(\alpha)$ determined from the following equation (Amer, 2007):

$$
\alpha=\frac{1}{C V}\left(\frac{d}{\bar{Z}}-1\right)--------
$$

where

$\mathrm{d}$ was the schedule depth which was taken equal to the minimum infiltrated depth $\left(Z_{\min }\right)$ in $\mathrm{mm}$ and $\bar{Z}_{\text {was }}$ the average infiltrated depth along the strip or the furrow in $\mathrm{mm}$.

Potato yield produced each experimental per unit volume of the used water ( $\mathrm{kg}$ yield $/ \mathrm{m}^{3}$ water) was evaluated as water use efficiency. Tuber dry matter percentage $(\%)$ was determined by drying the tuber slices at $70 \mathrm{C}^{\mathrm{o}}$ according to method of Dogras et al. (1991). Percentage of tuber size grade was taken $10 \mathrm{~kg}$ using by sizing rings

Percentage of tuber size was divided into four parts which were called seeds $<40 \mathrm{~mm}$, small $40-60 \mathrm{~mm}$, medium $60-80 \mathrm{~mm}$, large $>80 \mathrm{~mm}$. Large and seeds tubers are not manufactured for chips. Yield of chips was determined using the method of Wilbur( 1999) as the following equation was adopted: 


$$
\begin{aligned}
\text { Yield of chips } & =\frac{\text { Weight after frying (chips) }}{\text { Weight before frying (tubers) }} \\
& \times \text { yield of fresh tubers } \frac{\mathrm{Mg}}{\mathrm{ha}}
\end{aligned}
$$

\section{RESULTS AND DISCUSSIONS}

\subsection{Infiltrated irrigation depth and uniformity along furrow}

Results shown in Table 3 represent scheduling and evaluation parameters for all nine studied treatments. Depletion phase time was decreased as both water cutoff decreased and initial available soil water increased because the storage water on furrow ditch and soil infiltration rate were, respectively, smaller than those occurred in cutoff time after 5 min from water advanced the downstream end and $75 \%$ AW treatments. A minimum infiltrated depth $\mathrm{Z}_{\min }$ was occurred by applying $75 \%$ soil water regimes with water cutoff $5 \mathrm{~m}$ before water advanced the field end.

Table 3. Furrow irrigation scheduling by three Water cutoff times with three

\begin{tabular}{|c|c|c|c|c|c|c|c|c|c|}
\hline \multirow{2}{*}{$\begin{array}{l}\text { Evaluating } \\
\text { parameters } \\
\text { Soil AW* }\end{array}$} & After & $\begin{array}{c}5 \text { min fr } \\
\text { end }\end{array}$ & $m$ the & $\begin{array}{r}\text { Wa } \\
\text { Exact }\end{array}$ & $\begin{array}{l}\text { ter cut } \\
\text { y reach } \\
\text { end }\end{array}$ & $\begin{array}{l}\mathrm{ff} \\
\mathrm{d} \text { the }\end{array}$ & Befor & $\begin{array}{c}5 \mathrm{~m} \mathrm{fr} \\
\text { end }\end{array}$ & $\mathrm{m}$ the \\
\hline & $75 \%$ & $60 \%$ & $45 \%$ & $75 \%$ & $60 \%$ & $45 \%$ & $75 \%$ & $60 \%$ & $45 \%$ \\
\hline $\mathrm{T}_{\text {off }}(\min )$ & 13.35 & 17.033 & 20.1 & 10.16 & 13.25 & 16.51 & 9.41 & 12.81 & 16.15 \\
\hline $\mathrm{T}_{\mathrm{d}}(\min )$ & 2.0 & 2.05 & 3.283 & 1.035 & 1.715 & 1.867 & 1.0 & 1.515 & 1.18 \\
\hline$\alpha$ & $\begin{array}{c}- \\
0.013\end{array}$ & -0.01 & $\begin{array}{c}- \\
0.006\end{array}$ & $\begin{array}{c}- \\
0.017\end{array}$ & $\begin{array}{c}- \\
0.017\end{array}$ & $\begin{array}{c}- \\
0.006\end{array}$ & $\begin{array}{c}- \\
0.021\end{array}$ & -0.01 & $\begin{array}{c}- \\
0.018\end{array}$ \\
\hline $\mathrm{Z}_{\min }(\mathrm{mm})$ & 47.27 & 52.73 & 58.39 & 39.55 & 45.53 & 51.52 & 36.49 & 38.66 & 39.9 \\
\hline $\mathrm{Z}_{\max }(\mathrm{mm})$ & 83.36 & 83.83 & 85.29 & 43.63 & 57.38 & 59.31 & 40.69 & 59.29 & 51.01 \\
\hline$\overline{\mathrm{Z}}(\mathrm{mm})$ & 60.75 & 62.35 & 63.55 & 41.59 & 47.77 & 52.95 & 39.26 & 43.82 & 47.2 \\
\hline CV \% & 17.0 & 15.0 & 12.18 & 2.88 & 2.67 & 4.2 & 3.3 & 7.0 & 8.4 \\
\hline Du \% & 78.5 & 80.95 & 84.53 & 96.3 & 96.6 & 95.66 & 95.8 & 91.1 & 89.3 \\
\hline Еа \% & 77.8 & 84.6 & 91.89 & 94.8 & 95.1 & 97.11 & 92.94 & 88.2 & 84.5 \\
\hline I (d) & 19 & 24 & 28 & 19 & 24 & 28 & 19 & 24 & 28 \\
\hline
\end{tabular}
irrigation levels.

*AW is available water, $\mathrm{T}_{\text {off }}$ is water cutoff, $\mathrm{T}_{\mathrm{d}}$ is depletion phase time, $\alpha$ is schedule parameter, $Z_{\min }, Z_{\max } \cdot \bar{Z}$ are minimum, maximum and average infiltrated depths, respectively, $\mathrm{CV}$ is coefficient of variation, DU is distribution efficiency, $E_{a}$ is application efficiency, and $I$ is irrigation interval.

On the other hand, $\mathrm{Z}_{\max }$ was insignificantly changed by $75 \% \mathrm{AW}$ regime under water cutoff $5 \mathrm{~min}$ after water advanced field end treatment in 
which caused more water beyond rootzone. $\mathrm{Z}_{\max }$ was decreased by $75 \%$ AW regime under both water cutoff exactly and $5 \mathrm{~m}$ before water advanced downstream end in which both treatments decreased water seepage beyond rootzone. For a given water cutoff time, average depth $\bar{Z}$ was optimized under both 60 and $45 \%$ AW regimes. $Z_{\min }$ was nearly equal to $Z_{\max }$ by water cutoff of exactly and before $5 \mathrm{~m}$ from water flow was reached the field end. Infiltrated depth was increased along furrow because total recession time was larger than total advance time and storage stage. For a given water cutoff time, coefficient of variation CV, DU and $\mathrm{E}_{\mathrm{a}}$ were improved by 60 and $45 \% \mathrm{AW}$ treatments. Irrigation interval (I) was decreased applying 70\% AW and water cutoff after 5 min from reaching downstream end. Results showed that the best water distribution and application were acquired for water cutoff Levels as water flow exactly and before $5 \mathrm{~m}$ reached the field end. These results agreed with those obtained by Al-Kathiri (2009) and Amer (2009).

\subsection{Potato fresh and chips yields, dry matter and water use efficiency}

Data presented in Tables 4 and 5 showed significant differences among water cutoff times, irrigation levels and distances along furrow on tuber and chip yields, dry matter and water use efficiency. Results in Table 4 showed that the highest value of tuber and chips yields, dry matter and water use efficiency were occurred under both water cutoff before $5 \mathrm{~m}$ water advancing to downstream end and $75 \%$ AW, except dry matter which occurred under $45 \%$ AW treatment.

Regarding the interactions effect of both irrigation levels and water cutoff levels, data presented in table (4) showed significant differences yield the interactions effect between (irrigation levels and sample distances), (water cutoff levels and sample distances) and (irrigation levels, water cutoff levels and sample distances) that results showed that the interactions were significant.

Similar results were obtained by Amer (2011) on squash, reported that total yield increased under high level of soil moisture. El-Banna et al (2001), Alva et al (2002), Kashyap and panda (2003), Samey (2006) and Amer et al (2016) all of them on potato, they found that total tubers yield was significantly increased with increasing water supply and they reported that percentage of tubers dry mater was significantly increased 
with decreasing soil moisture and irrigation water rates ,also similar results were obtained by Gunnel and Karadogan (1998) and Samey (2006) on potato reported that, yield of chips was significantly increased as water rates decreased that may be due to increasing dry matter, specific gravity and starch contents of potato tubers.

Table 4. Means and standard errors for tuber yield

\begin{tabular}{|c|c|c|c|c|}
\hline \multirow[b]{2}{*}{ Items } & \multicolumn{4}{|c|}{ Mean $\pm \mathrm{SE}$} \\
\hline & Yield (Mg/ha) & WUE $\left(\mathrm{kg} / \mathrm{m}^{3}\right)$ & Dry matter \% & $\begin{array}{l}\text { Chip yield } \\
\text { (Mg/ha) }\end{array}$ \\
\hline \multicolumn{5}{|l|}{ Water cutoff time $(\mathrm{T})$} \\
\hline $\begin{array}{l}5 \quad \min \text { after } \\
\text { downstream end }\end{array}$ & $49.61 \pm 0.125^{\mathrm{A}}$ & $13.61 \pm 0.093^{\mathrm{A}}$ & $21.09 \pm 0.034^{\mathrm{A}}$ & $\begin{array}{l}16.51 \\
0.11^{\mathrm{A}}\end{array}$ \\
\hline $\begin{array}{ll}\text { Exactly } & \text { reached } \\
\text { downstream } & \end{array}$ & $51.02 \pm 0.125^{\mathrm{B}}$ & $15.99 \pm 0.093^{\text {В }}$ & $21.66 \pm 0.034^{\mathrm{B}}$ & $\begin{array}{l}17.45 \\
0.11^{\mathrm{B}}\end{array}$ \\
\hline $\begin{array}{l}\text { before } 5 \mathrm{~m} \text { from } \\
\text { downstream }\end{array}$ & $53.09 \pm 0.125^{\mathrm{C}}$ & $17.02 \pm 0.093^{\mathrm{C}}$ & $21.84 \pm 0.034^{\mathrm{C}}$ & $18.3 \pm 0.11^{\mathrm{C}}$ \\
\hline Irrigation Level (I) & & & & \\
\hline $\begin{array}{l}75 \% \text { AW } \\
60 \% \text { AW }\end{array}$ & 51.3 & $\begin{array}{l}15.89 \pm 0.093^{\mathrm{D}} \\
15.45 \pm 0.093^{\mathrm{A}}\end{array}$ & $\begin{array}{l}21.22 \pm 0.034^{\mathrm{A}} \\
21.52 \pm 0.034^{\mathrm{B}}\end{array}$ & $\begin{array}{l} \pm 0.11^{\mathrm{C}} \\
\pm 0.11^{\mathrm{B}}\end{array}$ \\
\hline $45 \% \mathrm{AW}$ & $44.34 \pm$ & $15.3 \pm 0.093^{\mathrm{A}}$ & $21.86 \pm 0.034^{\mathrm{C}}$ & $15.3 \pm 0.11^{\mathrm{A}}$ \\
\hline \multicolumn{5}{|c|}{ Distance along furrow (D) } \\
\hline $\begin{array}{l}0-20 \mathrm{~m} \text { of furrow } \\
\text { length }\end{array}$ & $48.26 \pm 0.125^{\mathrm{A}}$ & $14.6 \pm 0.093^{\mathrm{A}}$ & $21.52 \pm 0.034^{\mathrm{A}}$ & $\begin{array}{l}16.45 \\
0.11^{\mathrm{A}}\end{array}$ \\
\hline $\begin{array}{l}20-40 \mathrm{~m} \text { of furrow } \\
\text { length }\end{array}$ & $57.79 \pm 0.125^{\mathrm{B}}$ & $17.5 \pm 0.093^{\mathrm{B}}$ & $21.61 \pm 0.034^{\mathrm{B}}$ & ${ }_{\text {B }} 19.66 \pm 0.11$ \\
\hline $\begin{array}{l}40-60 \mathrm{~m} \text { of furrow } \\
\text { length }\end{array}$ & $47.66 \pm 0.125^{\mathrm{A}}$ & $14.51 \pm 0.093^{\mathrm{A}}$ & $21.46 \pm 0.034^{\mathrm{A}}$ & $\begin{array}{l}16.16 \\
0.11^{\mathrm{A}}\end{array}$ \\
\hline
\end{tabular}

*Significant at the $\mathrm{p} \leq 0.05$ level\& NS = non- significant

Table 5. Mean square, $\mathrm{F}$ value and probability for fresh tubers yield

\begin{tabular}{|c|c|c|c|c|c|c|c|c|c|}
\hline \multirow[b]{2}{*}{ Items } & \multirow[b]{2}{*}{ df } & \multicolumn{4}{|c|}{ Mean square } & \multicolumn{4}{|c|}{ F value and probability } \\
\hline & & $\begin{array}{l}\text { Yield } \\
\text { Mg/ha }\end{array}$ & $\begin{array}{l}\text { WUE } \\
\mathrm{Kg} / \mathrm{m}^{3}\end{array}$ & $\begin{array}{l}\text { Dry } \\
\text { matter } \\
\%\end{array}$ & $\begin{array}{l}\text { Chip } \\
\text { yield } \\
\mathrm{Mg} / \mathrm{ha}\end{array}$ & $\begin{array}{l}\text { Yield } \\
\mathrm{Mg} / \mathrm{ha}\end{array}$ & $\begin{array}{l}\text { WUE } \\
\mathrm{Kg} / \mathrm{m}^{3}\end{array}$ & $\begin{array}{l}\text { Dry } \\
\text { matter } \%\end{array}$ & $\begin{array}{l}\text { Chip } \\
\text { yield } \\
\mathrm{Mg} / \mathrm{ha}\end{array}$ \\
\hline Cutoff $(\mathrm{T})$ & 2 & 82.82 & 82.43 & 4.13 & 21.5 & $69.01 *$ & $701.1^{*}$ & $265.5^{*}$ & $131.3 *$ \\
\hline Irrigation (I) & 2 & 1261.1 & 2.732 & 2.74 & 120.8 & $1050.8^{*}$ & $23.23^{*}$ & $176.3 *$ & $735.3 *$ \\
\hline Distance (D) & 2 & 873.7 & 76.49 & 0.157 & 102 & $728.04 *$ & $650.5^{*}$ & $10.10^{*}$ & $621.1^{*}$ \\
\hline $\mathrm{I} * \mathrm{~T}$ & 4 & 269.9 & 24.90 & 0.057 & 30.1 & $224.9 *$ & $211.8^{*}$ & $3.65^{*}$ & $183.6^{*}$ \\
\hline $\mathrm{I} * \mathrm{D}$ & 4 & 137.0 & 9.736 & 0.239 & 14.1 & $114.2 *$ & $82.8^{*}$ & $15.36^{*}$ & $86.1^{*}$ \\
\hline $\mathrm{T} * \mathrm{D}$ & 4 & 98.51 & 8.969 & 1.007 & 11.1 & $82.09 *$ & $76.3 *$ & $64.75^{*}$ & $68.11 *$ \\
\hline $\mathrm{I} * \mathrm{~T} * \mathrm{D}$ & 8 & 94.75 & 9.376 & 0.088 & 11.1 & $78.96^{*}$ & $79.8^{*}$ & $5.63 *$ & $67.60 *$ \\
\hline Exp. Error & 54 & 1.2 & 0.118 & 0.016 & 0.164 & & & & \\
\hline
\end{tabular}




\subsection{Percentage of tuber size.}

Percentage of tuber size was significantly affected by 2015 spring season as presented in Tables 6 and 7. Data presented in Table 6 showed significant differences percentage of tuber size between three water cutoff times on percentage of tuber size. Data presented in table 7 showed significant between all water cutoff times with four parts of tuber size.

High yield percentage of seed tubers (culls) was at water cutoff $5 \mathrm{~min}$ from water advanced to downstream end and it was at $45 \%$ from AW and it was at the third part from the furrow. The low and best values were at water cutoff before water flow was reached the field end for $5 \mathrm{~m}$ and it was at $75 \%$ from AW and it was at the second part from the furrow.

Secondly, about small tuber, it showed that the highest value was at water cutoff after water flow was reached the field end for 5 min and was at $45 \%$ from AW. The lowest value was at water cutoff before water flow was reached the field end for $5 \mathrm{~m}$ and was at $75 \%$ from AW.

Thirdly, about medium tuber, it showed non-significant between all Water cutoff Levels, they were nearly equal. It showed that the highest and best value at $75 \%$ from $\mathrm{AW}$, and the lowest value was at $45 \%$ from AW.

Fourthly, about large tuber, the highest value was recorded as $9.98 \%$ at water cutoff when water flow was reached the field end, and the lowest value was recorded as $7.16 \%$ at water cutoff before water flow was reached the field end for $5 \mathrm{~m}$. Results percentage of tuber size was better under conditions of low water supply.

Regarding the interactions, data presented in table (6) showed significant differences percentage of tuber size the interactions effect between (irrigation levels and Water cutoff levels), (irrigation levels and sample distances) and (irrigation levels, Water cutoff levels and sample distances), and it showed non-significant between Water cutoff levels and sample distances.

Similar results were obtained by Amer (2011) on squash reported that, the percentage of large size increased with increasing soil moisture. ElBanna et al (2001), Samey (2006) and Amer et al (2016) all of them on potato, they reported that percentage of large tubers size was significantly 
increased as water rates increased and percentage of tuber seeds were significantly increased as soil moisture and water rates decreased .

Table (6): Mean square, F value and probability for fresh tubers size

\begin{tabular}{|c|c|c|c|c|c|c|c|c|c|}
\hline \multirow[t]{2}{*}{ Items } & \multirow[t]{2}{*}{ Df } & \multicolumn{2}{|c|}{ seeds $\%$} & \multicolumn{2}{|c|}{ small\% } & \multicolumn{2}{|c|}{ medium $\%$} & \multicolumn{2}{|l|}{ large $\%$} \\
\hline & & Mean & $\mathrm{F}$ & Mean & $\mathrm{F}$ & Mean & $\mathrm{F}$ & Mean & $\mathrm{F}$ \\
\hline $\begin{array}{l}\text { Cutoff time } \\
\text { (T) }\end{array}$ & 2 & 316.8 & $63.5^{*}$ & 352.5 & $46.8^{*}$ & 7.5 & $1 \mathrm{~ns}$ & 53.6 & $9.8^{*}$ \\
\hline $\begin{array}{l}\text { Irrigation } \\
\text { Level (I) }\end{array}$ & 2 & 927.3 & $186^{*}$ & 695.1 & $92.4 *$ & 1470.7 & $199.5^{*}$ & 330.9 & $60.8^{*}$ \\
\hline Distance(D) & 2 & 199.7 & $40^{*}$ & 190.2 & $25.2 *$ & 184.6 & $25^{*}$ & 19.2 & $3.5^{*}$ \\
\hline $\mathrm{I}^{*} \mathrm{~T}$ & 4 & 187.4 & $37.6^{*}$ & 57.1 & $7.5^{*}$ & 44.7 & $6^{*}$ & 18.5 & $3.4^{*}$ \\
\hline $\mathrm{I}^{*} \mathrm{D}$ & 4 & 38.4 & $7.7 *$ & 113.3 & $15^{*}$ & 98.6 & $13.4^{*}$ & 23.4 & $4.3^{*}$ \\
\hline $\mathrm{T} * \mathrm{D}$ & 4 & 26.9 & $5.4^{*}$ & 35.1 & $4.6^{*}$ & 59.6 & $8.1^{*}$ & 3.2 & $0.6 \mathrm{~ns}$ \\
\hline $\mathrm{I} * \mathrm{~T} * \mathrm{D}$ & 8 & 13 & $2.6^{*}$ & 24.1 & $3.2 *$ & 37.4 & $5.1^{*}$ & 31.3 & $5.7^{*}$ \\
\hline Exp. Error & 54 & 4.9 & & 7.5 & & 7.3 & & 5.4 & \\
\hline
\end{tabular}

Table (7): Means and standard errors for tubers size

\begin{tabular}{|c|c|c|c|c|}
\hline \multirow{2}{*}{ Items } & \multicolumn{4}{|l|}{ Mean \pm SE } \\
\hline & Seeds $\%$ & Small $\%$ & Medium $\%$ & large $\%$ \\
\hline \multicolumn{5}{|c|}{ Water cutoff Level } \\
\hline After $5 \mathrm{~min}$ & $16.08 \pm 0.6^{\mathrm{C}}$ & $23.77 \pm 0.74^{\mathrm{A}}$ & $51.45 \pm 0.74^{\mathrm{A}+}$ & $8.68 \pm 0.63^{B}$ \\
\hline Exactly reached & $11.46 \pm 0.6^{\mathrm{B}}$ & $26.45 \pm 0.74^{\text {B }}$ & $51.99 \pm 0.74^{\mathrm{A}+}$ & $9.98 \pm 0.63^{C}$ \\
\hline $\begin{array}{l}\text { Before } 5 \mathrm{~m} \\
\text { Irrigation Level }\end{array}$ & $9.4 \pm 0.6^{\mathrm{A}}$ & $30.92 \pm 0.74^{\mathrm{C}}$ & $52.51 \pm 0.74^{\mathrm{A}+}$ & $7.16 \pm 0.63^{\mathrm{A}}$ \\
\hline $75 \%$ AW & $7.08 \pm 0.6^{\mathrm{A}}$ & $22.5 \pm 0.74^{\mathrm{A}}$ & $58.13 \pm 0.74^{\mathrm{C}}$ & $11.6 \pm 0.63^{\mathrm{C}}$ \\
\hline $60 \% \mathrm{AW}$ & $10.2 \pm 0.6^{\mathrm{B}}$ & $26.19 \pm 0.74^{\mathrm{B}}$ & $54 \pm 0.74^{\mathrm{B}}$ & $9.4 \pm 0.63^{\mathrm{B}}$ \\
\hline $45 \% \mathrm{AW}$ & $18.9 \pm 0.6^{\mathrm{C}}$ & $32.5 \pm 0.74^{\mathrm{C}}$ & $43.8 \pm 0.74^{\mathrm{A}}$ & $4.75 \pm 0.63^{A}$ \\
\hline \multicolumn{5}{|l|}{ Sample distance } \\
\hline $\begin{array}{l}0-20 \mathrm{~m} \text { from } \\
\text { furrow }\end{array}$ & $12.18 \pm 0.6^{\mathrm{B}}$ & $30.09 \pm 0.74^{\mathrm{B}}$ & $49.9 \pm 0.74^{\mathrm{A}+}$ & $7.8 \pm 0.63^{\mathrm{A}}$ \\
\hline $\begin{array}{l}20-40 \mathrm{~m} \text { from } \\
\text { furrow }\end{array}$ & $9.6 \pm 0.6^{\mathrm{A}}$ & $25.8 \pm 0.74^{\mathrm{A}+}$ & $54.93 \pm 0.74^{\mathrm{B}}$ & $9.5 \pm 0.63^{\mathrm{B}}$ \\
\hline $\begin{array}{l}40-60 \mathrm{~m} \text { from } \\
\text { furrow }\end{array}$ & $15.09 \pm 0.6^{\mathrm{C}}$ & $25.23 \pm 0.74^{\mathrm{A}+}$ & $51.1 \pm 0.74^{\mathrm{A}+}$ & $8.5 \pm 0.63^{\mathrm{AB}}$ \\
\hline
\end{tabular}

*Significant at the $\mathrm{p} \leq 0.05$ level \&ns = non- significant. 


\section{CONCLUSION}

Yield of fresh potato was significantly increased with increasing soil moisture content. At water cutoff level, the highest value was recorded as $53.088 \mathrm{Mg} / \mathrm{ha}$ at water cutoff before water flow was reached the field end for $5 \mathrm{~m}$. About irrigation level, the highest value was recorded as 58.0 $\mathrm{Mg} / \mathrm{ha}$ at $75 \%$ from available water

The highest value of water use efficiency was recorded as $17.018 \mathrm{~kg} / \mathrm{m}^{3}$ at water cutoff $5 \mathrm{~m}$ before water advanced the field end. For a given irrigation cutoff, the highest value was recorded as $15.89 \mathrm{~kg} / \mathrm{m}^{3}$ at $75 \%$ from available water.

The highest value of dry matter and specific gravity for potato tubers were obtained under $45 \%$ soil available water. Furthermore, the highest value of dry matter for potato tubers was obtained under water cutoff before $5 \mathrm{~m}$ water advanced to downstream end.

The best values for manufacturing potato chips were at low level of water supply which is water cutoff $5 \mathrm{~m}$ before water advanced downstream end because it had low values from Large and seeds tubers.

Chips yield was significantly decreased by increasing water cutoff level and the highest value was recorded as $18.3 \mathrm{Mg} / \mathrm{ha}$ at water cutoff at before $5 \mathrm{~m}$ water advanced the field end. For a given irrigation regimes, chips yield was significantly increased with increasing soil moisture content and the highest value was recorded as $19.5 \mathrm{Mg} / \mathrm{ha}$ at $75 \%$ from available water. The best values of potato tuber yield and quality were in furrow location in between 20 to 40 compared to the obtained results from 0 to $20 \mathrm{~m}$ and 40 t0 $40 \mathrm{~m}$ furrow locations.

\section{REFERENCES}

AbouKheira, A.A. (2009) Comparison among Different Irrigation Systems for Deficit-Irrigated Corn in the Nile Valley. Agricultural Engineering International: CIGR Journal, 14, 1-25.

Aksic, M.; N. Gudzic.; N. Deletic.; S. Gudzic.; S. Stojkovic.; J. Knezevic.; S. Barac; (2012).Effects of soil matric potential on tuber yield and evapotranspiration of potato. International Symposium for Agriculture and Food, XXXVII Faculty Economy Meeting, IV Macedonian Symposium for Viticulture and Wine Production, VII Symposium for 
Vegetables and Flower Production, Skopje, Macedonia, 12-14 December 2012; 2012. : 1-8. 32 ref.

Alva, A.K.; T. Hodges; R.A. Boydston and H.P. Collines, (2002): effect of irrigation and tillage practices on yield of potato under high production conditions in the Pacific Northwest. Communication in soil science and plant Analysis, 33 (9-10):1451-1460.

Al-Kathiri, M. (2009). Water storage and conductivity in soils as related to irrigation systems. M. Sc. Agric. Sci." Soil Science "Menoufia University, Egypt.

Amer, K. H. (2007). Surface irrigation evaluation based on analytical interrelation among water infiltration, advance and recession. Proceeding of Irrigation Association 9-11 Dec in San Diego, CA: 433-445.

Amer, K.H. (2009) The Possibility of Improving Surface Irrigation with Blocked End in Sparse Grape Trees. Misr Journal of Agricultural Engineering, 26, 836-862.

Amer, K.H. (2010). Corn crop response under managing different irrigation and salinity levels. Agr. Water Manage., (97): 1553-1663.

Amer, K.H. (2011) Effect of Irrigation Method and Quantity on Squash Yield and Quality. Agricultural Water Management, 98,1197-1206.

Amer K. H., Abdellateif A. Samak, Jerry L. Hatfield., (2016). Effect of irrigation method and non-uniformity of irrigation on potato performance and quality. Journal of Water Resource and Protection, 2016, 8, 277-292. [Online],Available from http://www.scirp.org/journal/jwarp

Bosnjak. D. and B. Pejic, (1997)_: potato water requirement in the Chernozem zone of Yugoslavia. Acta Hort., 449(1): 211-215.

Dogras, C.;A. Siomos and C. Psomakelis, (1991): sugar and dry matter changes in potatoes stored in a clamp in a mountainous region of Northern Greece. Potato Res., 34:211-214.

El-Banna, E.N.; A-F.H. Selim and H.Z. abdel-El-Salam, (2001): Effect of irrigation methods and water regimes on potato plant (Solanum tuberosum L.) under delta soil conditions. Minufiya J. Agric. Res. 26(1):1-11. 
Gunel, E., and T. Karadogan, (1998): Effect of irrigation applied at different growth stages and length of irrigation period on quality characters of potato tubers. Potato Res. 41(1):9-19.

Karafyllidis, D. I; N. Stavropoulos and D. Geargkls, (1996): The effect of water stress on the yielding capacity of potato crops and subsequent performance of seed tubers. Potato Res. 39(2):153-163.

Kashyap, P. S. and R. K. Panda. (2003): effect of irrigation scheduling on potato crop parameters under water stressed conditions. Agric. Water Management. 59(1):49-66.

Podstawka, C. E., and L. Maliki, (1997): Reaction of potatoes to spray irrigation and nitrogen fertilizers on light soil. AnnalesUniversatatisMariaeCuriesklodowska section E., Agric., 52,7783 (C.F. Field Crop Abstr., 51 (10) 7689,1998).

Samey, M. M. (2006): The response of potato (solanum tuberosum, L) to water regimes and irrigation systems. Ph.D. (Agric.) Thesis, Faculty of Agriculture, University of Minoufiya, Egypt.

Wilbur A. (1999): Potato production, processing \& technology. CTI PUPLIVATION, INC. Timonium, Maryland 21093-4247USA, ISBN: 0930027-30-2 pp. (42-63).

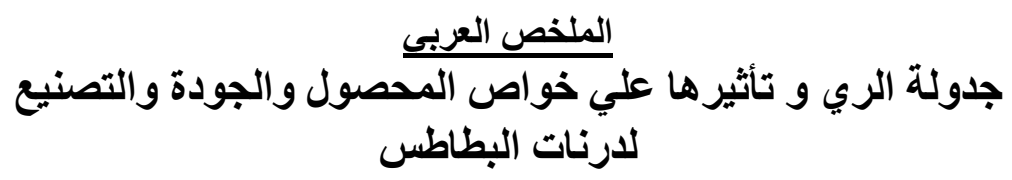

كمال حسني حنفي عامر' محمد علي حسن ابوعميرة' محمود إبراهيم سليمان سلام

أجريت هذه الدر اسة خلال موسم 10 ـ ب الربيعي للبطاطس وذللك بمنطقة قويسنا بشمال مصر بتربة طينية لدراسة تأثثر جدولة الري باستخدام نظام الري السطحي بالخطوط مزودة بالأنابيب المبوبة وذللك على خواص محصول البطاطس وجودة الدرنات وجودة تصنيعها على هيئة شر ائح شيبسي ، أجريت هذه الدر اسة على صنف بطاطس هيرمس باستخدام تقاوي مستوردة من

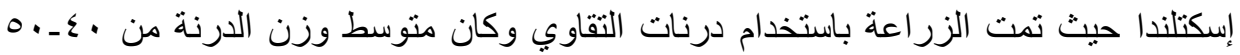

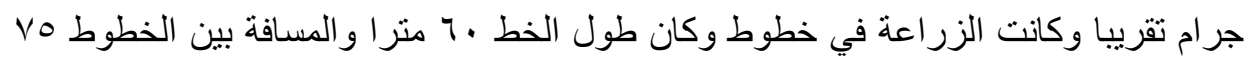

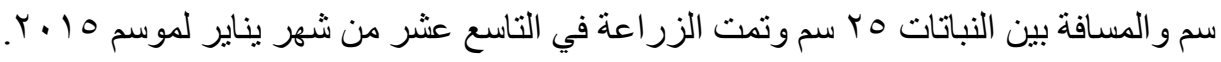

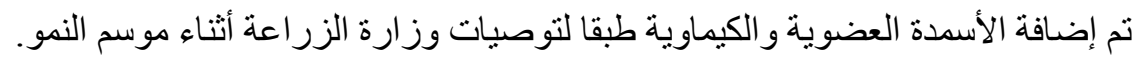

1 ـ أستاذ الري والصرف ب ـ طالب ماجستير قسم الهندسة الزراعية ـ جامعة المنوفية 


\section{اشتملت التجربة على دراسة:}

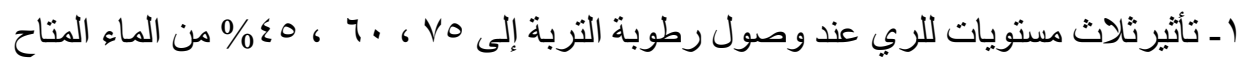

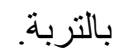

rـ تأثثير مستويات قطع المياه عن الخط وهم قطع المياه عند وصول موجة المياه إلى (قبل نهاية

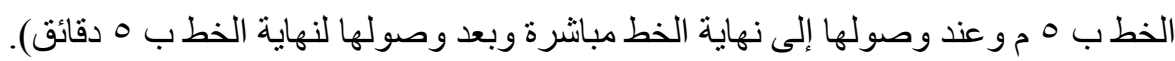
بـ تأثير مكان أخذ العينة على طول الخط على صفات النمو وخو اص الجودة وتصنيع الدرنات. عـ تأثثير التفاعل بين الفترة بين الريات وزمن إضافة المباه داخل الخطو أماكن أخذ العينة. تم قياس الاختلافات بين معاملات الري كالآتي: - إنتاجية الدرنات:

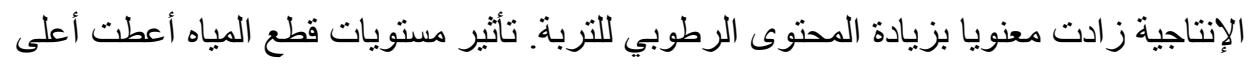

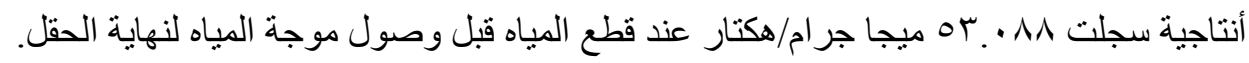

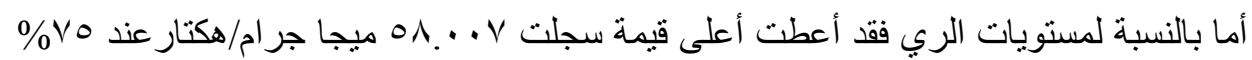

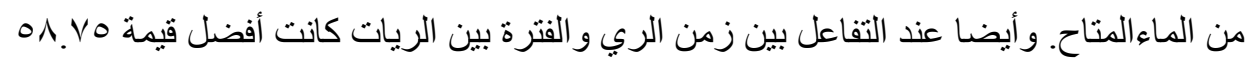

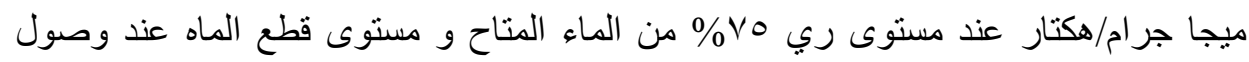

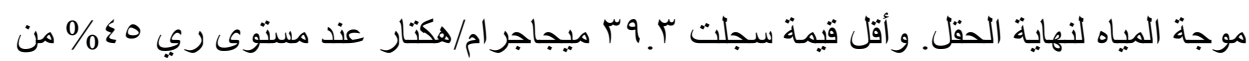

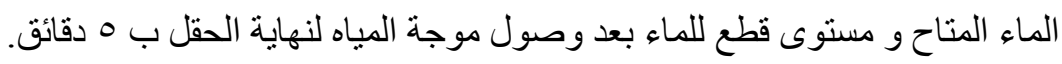

ـ كفاءة استخدام المياه:

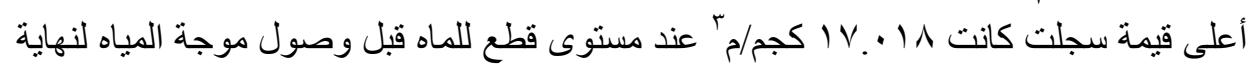

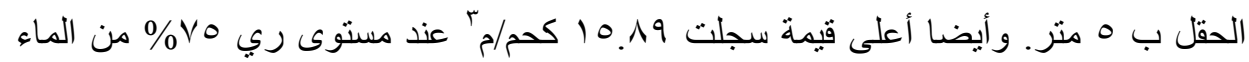

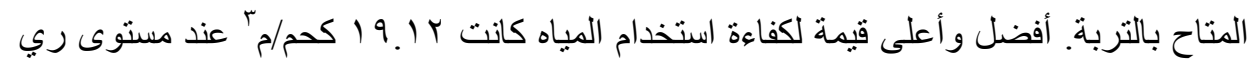

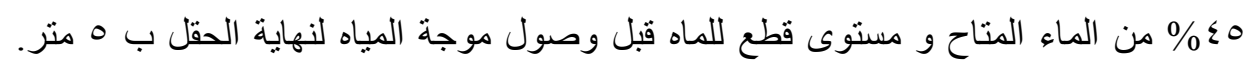

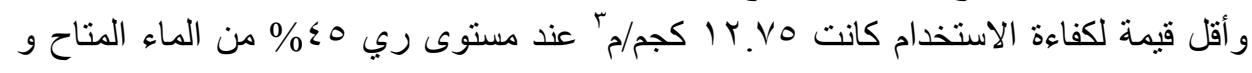

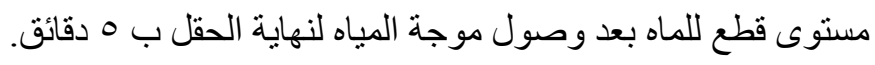

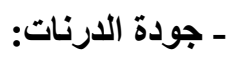

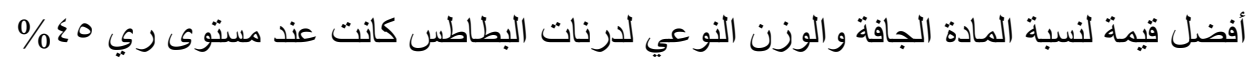

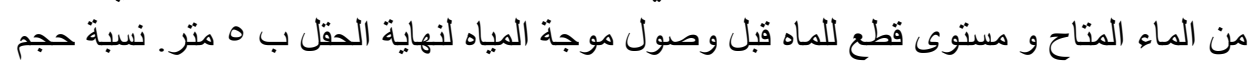

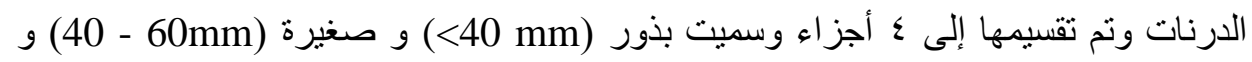

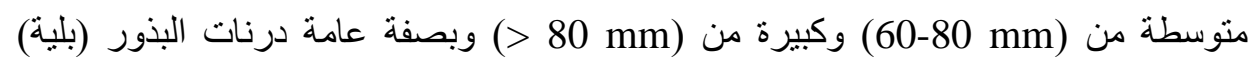

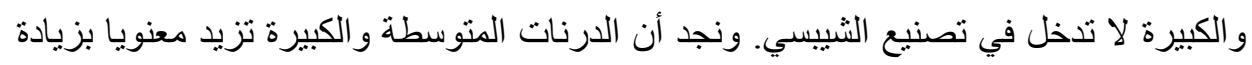

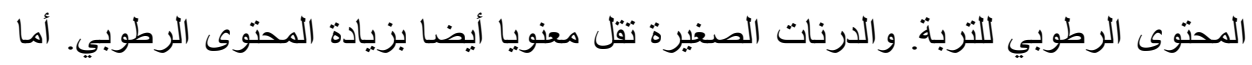


تأثثر زمن الري على نسبة حجم الدرنات المتوسطة كان غير معنويا على جميع مستويات زمن

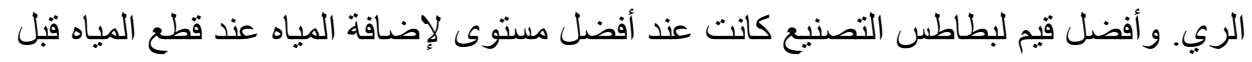

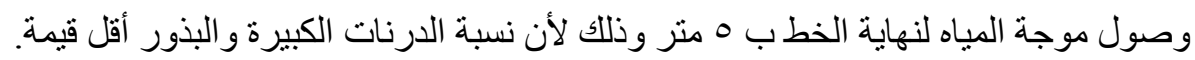

\section{ـ الخواص التصنيعية للارنات و إنتاجية الثييسي}

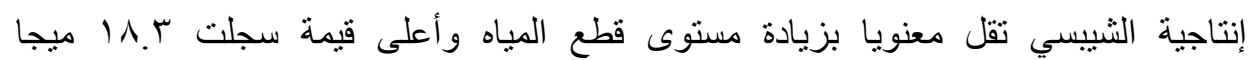

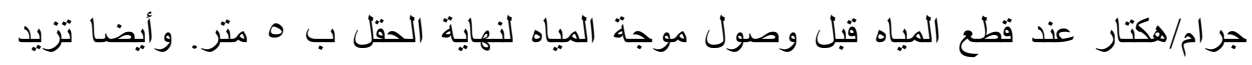

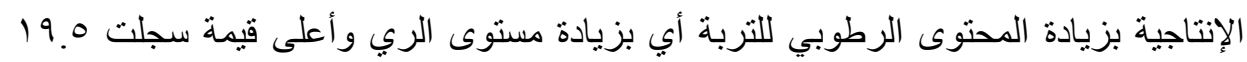

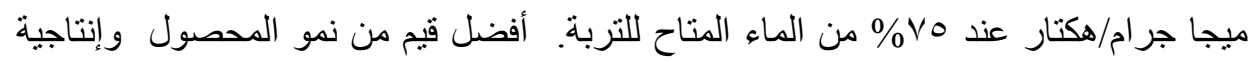

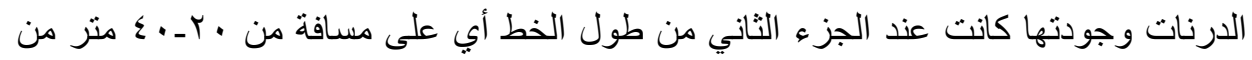

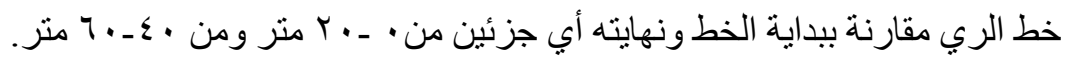

